\title{
PEMETAAN ALIRAN PEMIKIRAN DAKWAH DITINJAU DARI PERIODISASI GERAKAN DAKWAH DAN KONSEP KEILMUAN
}

Asna Istya Marwantika*

\begin{abstract}
Dakwah activity in the society has grown rapidly, but it was developed still practical and yet provide a meaningful contribution in the theoretical realm. Therefore, it would need to do the literature search to identify the period of the dakwah movement of the time of the Prophet Muhammad until today. In addition it should also identify the defining concept of dakwah from the academics, have it dakwah concept is tailored to the needs of society and the development of post-positivistic era or dakwah still require elaboration of new concepts to address the challenge of the complexity of the society .
\end{abstract}

\section{PENDAHULUAN}

Memasuki milenium ketiga, tantangan terhadap gerakan dakwah sangat kompleks, baik yang bersifat konkret maupun ideologis. Munculnya ilmu pengetahuan dan teknologi dalam era ini mengakibatkan berbagai dampak dalam bentuk agresi politik, kultural, ekonomi, dan ideologi yang memarjinalisasikan dan mendiskualifikasikan struktur tradisional masyarakat yang telah mapan. ${ }^{1}$

Di era agama yang telah terprivatisasi, konsep-konsep dakwah yang dulu dirumuskan para pakar, saat ini terasa tidak bersinergi. Terlebih dalam konsep yang memposisikan mad'u sebagai obyek dakwah yang pasif dan hanya menerima apa yang disampaikan seorang da'i. Pemikiran-pemikiran dakwah yang ada menempatkan seorang da'i pada posisi powerful diatas kepasifan mad'u.

\footnotetext{
*Dosen Tetap Fakultas Dakwah INSURI Ponorogo

${ }^{1}$ Derasnya arus informasi di era milenium ketiga ini lebih lanjut dibahas oleh Alvin Toffler dalam The Third Wave, juga bisa dilihat di Ziauddin Sardar dalam Tantangan Dunia Islam Abad 21: Menjangkau Informasi (Bandung: Mizan, 1985).
} 
Pemikiran ini diperparah dengan misunderstanding masyarakat terhadap dakwah itu sendiri, bahkan setingkat mahasiswa dan sarjana lulusan Perguruan Tinggi Islam masih menganggap dakwah hanyalah sekedar aktifitas tablig dan ceramah di podium. Hal seperti ini sering penulis temui di lapangan ketika berinteraksi dengan mereka. Misunderstanding dakwah ini juga berkelindan dengan tidak banyaknya pemikiran yang dihasilkan di bidang keilmuwan dakwah. Riset-riset dakwah yang berkembang lebih memfokuskan pada dakwah sebagai gerakan atau aktifitas dakwah, bukan pada keilmuwannya, terlebih dari aspek filosofisnya. Tidak tanggungtanggung, dari beberapa konferensi internasional dalam studi Islam, para pemikir dan pemerhati dakwah yang hadir masih belum menelorkan konsep pengembangan dakwah. Apalagi di tingkat mahasiswa fakultas dakwah, sangat sulit diharapkan.

Salah satu aspek keilmuwan dakwah yang jarang dilakukan adalah pemetaan pemikiran dakwah. Selama ini yang sering dilakukan adalah pemetaan paradigma pergerakan dakwah. Dari literatur yang telah ditelusuri, tulisan ini akan mengupas pemikiran beberapa pakar dakwah dan membandingkannya dengan tradisi keilmuwan sosial.

\section{PERIODISASI GERAKAN DAKWAH}

Istilah dakwah tidak pernah mendapat definisi yang eksplisit dari Nabi, baik dari perilakunya maupun ucapannya. Hal ini berbeda dengan istilah puasa, haji, dan sholat yang telah dijelaskan Nabi dari arti etimologis menjadi arti sakral yang merefer pada peribadatan dalam Islam. Maka wajar jika kemudian pengikut Nabi mencoba membatasi pengertian dakwah. Mereka berusaha mengidentifikasi tindakantindakan tertentu mana saja yang masuk dalam cakupan makna dakwah. Oleh karena itu, dalam sejarah umat Islam, pengertian dakwah mengalami penyempitan dan perluasan makna. Dalam hal ini, dakwah bisa didefinisikan sebagai ajakan kepada orang lain agar menerima ajaran perorangan atau kelompok yang mengklaim sebagai yang absah menduduki kursi kekhalifahan, karena itu diyakini sebagai bagian dari agama.

Di masa Sahabat, Tabi'in dan Dinasti Umayyah, paradigma dakwah Islam lebih mengarah pada pembebasan kaum nonmuslim dari kesyirikan agar mendapat cahaya Islam. Pada masa-masa tersebut, dakwah lebih difokuskan pada pembebasan 
negeri-negeri kafir. Hasilnya, pada periode awal setelah wafatnya Nabi ini adalah perluasan Islam ke berbagai penjuru di luar jazirah Arab, yang asalnya dikuasai oleh imperium Bizantium dan Sasania. Menurut Hossein Nasr, proses Islamisasi ini dilakukan dengan dua gelombang, pertama menggunakan kekuatan senjata, dan yang kedua jalan damai. ${ }^{2}$ Meskipun banyak sarjana Barat yang mencurigai, konversi agama dari penduduk taklukkan kepada agama Islam. Mereka mempertanyakan apakah memang penduduk taklukkan tersebut memeluk Islam murni karena panggilan nurani atau ada motif-motif lain seperti paksaan atau kepentingan politik dan sosial. Namun, menurut Ira M. Lapidus, sangat sedikit perpindahan ke agama Islam yang berlangsung dengan paksaan. ${ }^{3}$ Paradigma ini kurang memfokuskan dakwah dalam bentuk karya tulisan, ${ }^{4}$ karenanya dakwah bi al-lisa $>n$ tidak terlalu berkembang dalam periode ini, barulah pada abad selanjutnya, setelah banyaknya non muslim dan non Arab yang memeluk Islam, ada kebutuhan mendesak untuk menjelaskan kandungan al-Qur`an dan hadis kepada khalayak yang tidak memiliki pengetahui bahasa Arab dan berlatar belakang bukan arab. Akibatnya, serangkaian ilmu dikembangkan untuk memecahkan masalah-masalah ini, dan hampir semua kehidupan intelektual terkonsentrasi pada pengembangan ilmu-ilmu Islam tersebut. ${ }^{5}$

\footnotetext{
${ }^{2}$ Seyyed Hossein Nasr, Islam Religion History and Civilization (New York: Harper San Fransisco, 2003), 17. Pernyataan sejarawan yang mengemukakan bahwa Islam disebarkan tidak hanya dengan senjata tapi dengan cara damai juga bisa dilacak pada karya Thomas Arnold dan Hugh Kennedy. Lebih lanjut lihat Thomas W Arnold, Sejarah Dakwah Islam, terj. Abdullah (Jakarta: Widjaya, 1981), 43, 120. Dan Hugh Kennedy, The Prophet and the Age of the Caliphates (London: Logman, 1991), 59. Bahkan Mas'ud al-Tawir menganggap masyarakat Persia memeluk Islam karena pengaruh ajaran Islam yang mereka anggap lebih baik dari agama terdahulu. Silahkan lihat H\{asan Mas'u>d al-T\{a>wir, al-Da'wah ila $>$ Alla $>h$ Ta' $a>l a>$ 'ala $>$ D\{au $i$ alKita $>$ b wa al-Sunnah (Beirut: Dar al-Qutaybah, 1992), 170.

${ }^{3}$ Bahkan menurut Hodgson, karena kebijakan pluralis yang dilakukan Dinasti Abbasiyah, ketika para elit istana tidak lagi dikuasai etnis Arab, masyarakat non Arab semakin tertarik masuk Islam. Menjadi muslim merupakan sebuah prestise saat itu, apalagi jika ingin meniti karir, menjadi Islam adalah pilihan utama. Islam menjadi lencana dari massa yang berorientasi kota kosmopolitan, sebuah simbol mobilitas sosial yang baru saat itu. Lihat Marshall G. S. Hodgson, The Venture of Islam: Iman dan Sejarah dalam Peradaban Dunia, buku kedua, terj. Mulyadhi Kartanegara (Jakarta: Paramadina, 2002), 93-94. Untuk mengetahui lebih lajut pola-pola konversi ke Islam yang terjadi mulai dari Dinasti Abbasiyah sampai Andalusia, India, Turki dan Indonesia, silahkan lihat Ira M. Lapidus, Sejarah Sosial Umat Islam, bag.1 dan 2, terj. Ghufron A. Mas'adi (Jakarta: Raja Grafindo Persada, 2000), 376-391.

${ }^{4}$ Walaupun ada beberapa aktifitas dakwah dengan tulisan, pada masa ini lebih sesuai disebut sebagai masa perintisan, sehingga belum begitu berkembang. Lihat Wahyu Ilaihi dan Harjani Hefni Polah, Pengantar Sejarah Dakwah (Jakarta: Kencana Prenada, 2012), 113-115.

${ }^{5}$ Sebagaimana dijelaskan Hugh Kennedy, pada abad pertama Islam, dua isu penting yang membentuk latar belakarang kebudayaan Islam adalah politik kepemimpinan yang melahirkan sunni dan syi'ah serta penyebaran Islam. Hugh Kennedy, Kehidupan Intelektual Islam pada Empat Abad Pertama Islam, dalam Farhad Daftary, ed,. Tradisi-Tradisi Intelektual Islam, terj. Fuad Jabali dan Udjang Tholib (Jakarta: Erlangga, 2001), 29-34.
} 
Barulah di masa Abbasiyah, pengembangan paradigma dakwah dilakukan lebih leluasa. Hal ini karena perluasan wilayah dan pembebasan tidak terlalu sering dilakukan. Sehingga penguasa dan ulama terkonsentrasi pada pengembangan ilmu pengetahuan dan keilmuwan Islam lainnya. Al-Baya>nu>ni> menyebutkan dakwah pada masa Daulah Abbasiyah dilakukan melalui dua sektor, sektor yang dilakukan oleh pemerintah dan sektor yang dijalankan oleh rakyat. ${ }^{6}$ Paradigma ini menimbulkan perkembangan dakwah dalam berbagai bidang keilmuwan seperti tafsir, hadis, gramatika Arab, hukum Islam, pemerintahan, dan lain-lain. Dakwah yang dijalankan pemerintah dan rakyat bersinergi membentuk kebudayaan gemilang pada saat itu. ${ }^{7}$

Namun perlu dicatat, di awal kampanye Bani Abbas, dakwah dimaknai sebagai ajakan kepada orang lain agar menerima ajaran perorangan atau kelompok yang mengklaim sebagai yang absah menduduki kursi kekhalifahan, karena itu diyakini sebagai bagian dari agama untuk mengikuti. Dalam sejarah Dinasti Abbasiyah, perebutan kursi kekhalifahan dari dinasti Umayyah disebut sebagai gerakan dakwah ditandai misalnya dengan slogan, rid\}a> min a>li Muhjammad (mencari kerelaan dari keluarga Nabi Muhammad saw). Di kalangan Syi'ah, istilah dakwah dalam politik keagamaan memasukkan aktifitas ajakan untuk setia pada Imam yang turun dari Ismail bin Ja'far al-S \{adi>q. Aktifitas dakwah ini melahirkan revolusi Qaramit\}ah Isma>i>'liyyah di Syiria pada 902-907 M, yang puncaknya pada pendirian Dinasti Fatimiyah di Mesir.

Pada masa keemasan Dinasti Fatimiyah di Mesir, dakwah mewujud secara hierarkis dalam bentuk tingkatan-tingkatan da'i sejak dari wilayah paling rendah, sampai ke pusat pemerintahan. Da'i pada masa ini mempunyai kekuasaan untuk membina keberagamaan pengikut pemula aliran Ismailiyah sekaligus membimbing kegiatan spiritualnya agar sampai pada tahap setinggi-tingginya dalam tradisi Syi'ah. Dalam ajaran Syi'ah Isma'iliyah, dakwah antara lain berbentuk pendidikan dan proses indoktrinasi ajaran pemikiran dalam bidang politik, hukum, sistem kepercayaan maupun filsafat, secara formal dakwah dikelola oleh negara. ${ }^{8}$

\footnotetext{
${ }^{6}$ Muh\}ammad Abu> al-Fath\} al-Baya>nu>ni>, al-Madkhal ila> 'Ilm al-Da'wah (Beirut: Muassasat alRisa>lah, 1993), 101.

${ }^{7}$ Mustafa Husni al-Siba'i, Khazanah Peradaban Islam, terj. Abdullah (Bandung: Pustaka Setia, 2002), 197.

${ }^{8}$ Demikian yang dikutip Muhammad Sulthon dari The Encyclopaedia of Islam. Muhammad Sulthon, Desain Ilmu Dakwah: Kajian Ontologis, Epistemologis dan Aksiologis (Yogyakarta: Pustaka Pelajar, 2003), 13-14.
} 


\section{POLA GERAKAN DAKWAH}

Ilyas Ismail mengklasifikasikan paradigma dakwah berdasar gerakan yang dilakukan pelakunya menjadi tiga paradigma, yaitu paradigma tablig, paradigma pengembangan masyarakat, paradigma harakah dan paradigma kultural. ${ }^{9}$

\section{Paradigma Tablig}

Tablig (pidato atau ceramah) merupakan bagian penting dari dakwah. Meskipun begitu, tablig sejatinya tidak dapat diidentikkan dengan dakwah karena cakupan pengertiannya yang sempit dan praktiknya yang amat terbatas. Namun demikian, tablig sebagai suatu proses penyampaian ajaran Islam merupakan bagian integral yang tidak mungkin untuk dilampaui. Karena bagaimanapun juga, dakwah dengan cakupan garapannya yang luas itu, tidak mungkin dilakukan tanpa tablig.

Terkait dengan hal diatas, hadis Nabi yang acapkali dikutip untuk menegaskan kewajiban dakwah, secara redaksional juga menggunakan terminologi tablig. Adapun dalam al Qur'an, banyak sekali ditemukan ayat yang menegaskan posisi Nabi sebagai penyampai risalah Tuhan $(a l-b a l a>g) .{ }^{10}$ Dalam pidatonya di akhirakhir usia beliau ketika haji perpisahan, salah satu hal yang dikonfirmasikan Rasulullah dihadapan para sahabat adalah perihal terkait dengan tanggung jawabnya sebagai seorang muballig. Dalam kata tablig itu sendiri sejatinya terkandung makna proses, yakni proses untuk mengusahakan sesuatu agar bisa sampai kepada tujuan akhir, baik dalam wujud tempo, dan ruang maupun keadaan.

Walaupun begitu, belakangan istilah tablig mengalami pereduksian makna. Tablig tidak lagi dipandang sebagai suatu proses dari tahapan panjang dakwah, tapi justru menggeser posisi dakwah ini sendiri. Pola pikir ini hanya memandang dakwah tak lebih dari sekedar tablig, yaitu kegiatan penyampaian ajaran agama kepada khalayak (publik). Dari sini, maka penyebutan dakwah menjadi akrab dikenal dengan tablig, dan da'i tidak lain mubaligh itu sendiri. Dalam perkembangan berikutnya, dakwah dipandang tidak berbeda, alias identik dengan

\footnotetext{
${ }^{9}$ Ilyas Ismail dan Prio Hotman, Filsafat Dakwah; Rekayasa Membangun Peradaban Islam (Jakarta: Kencana: 2011), 213-214.

${ }^{10}$ Lihat misalnya QS. 3:20, 5:92, dan 99, 13:40, 16:35 dan 82, 24:54, 29:18, dan 36:17.
} 
ceramah dan khotbah-khotbah. Penentuan kriteria da'i, mengikuti pola pikir ini, menjadi dibatasi hanya terhadap mereka yang aktif berceramah lewat mimbarmimbar, dan bukan kepada selainnya walaupun tergolong aktif mewujudkan Islam lewat pemikiran atau tindakan. Paradiga dakwah yang demikian ini, lebih lanjut dikenal dengan mazhab dakwah tablig. Dari fenomena yang terlihat, kebanyakan praktik dakwah di dunia muslim berada dalam kategori mazhab tablig. Kenyataan ini diamini, terutama oleh mindset umat muslim yang masih sulit membedakan antara dakwah dan tablig. Di Indonesia sendiri, pola pikir seperti ini, dapat dilihat misalnya dalam penggunaan label dakwah untuk mewakili penyebutan ceramah atau khotbah.

Secara historis, gerakan dakwah dengan paradigma tablig diprakarsai oleh seorang ulama dari India bernama Muh\}ammad ibn Ilya>s ibn Muh \}ammad Isma>'i>l al-Kandahlawi> (1882-1943 M). Tokoh ini merupakan penganut teologi Maturidiyah, fikih mazhab Hanafi dan pengikut tarekat sufi al-Jisti, sebuah tarekat tasawuf yang didirikan oleh Mu'inuddin al-Jisti>. Pendiri gerakan dakwah ini, merasa prihatin menyaksikan masyarakat muslim di Mewat semakin jauh dari ajaran Islam yang benar dan berbaur dengan orang-orang Majusi penyembah berhala, bernama dengan nama-nama mereka, bahkan tiada yang tersisa dari keislaman mereka kecuali hanya sebutan saja ${ }^{11}$. Lahir dari keprihatinan ini, al-Kandahlawi> bertukar pikiran dengan para pemuka agama dan disarankan untuk menggalakkan dakwah tablig di India. Dalam perjalanan selanjutnya, gerakan dakwah tablig mendapatkan banyak pengikut mulai dari benua Asia, Afrika, Eropa hingga Amerika. ${ }^{12}$ Sebagai wujud gerakan, orang banyak menyebut pengikut paradigma tablig dengan jamaah tablig. Penyebutan ini agaknya lebih dinisbatkan kepada aktivitas dakwah yang lebih banyak menekan unsur penyampaian (tablig).

Menurut para pendukung paradigma tablig, umat muslim dibebani kewajiban untuk menyampaikan risalah Islam dan mengorbankan harta dan jiwa mereka. Bagi mereka, tugas utama umat Islam adalah berdakwah, mengajak orang kepada Allah dan menyebarkan agama, hidayah dan perdamaian dan niat berkerja demi

\footnotetext{
${ }^{11}$ Muh ammad Junayd 'Abd al-Majid, Jama > 'at al-Tabli $>g$ fi $>$ al-Hind Dira $>$ sah wa al-Taqwi $>m$, ( Makkah: Mat\}ba'ah al-Jama>'ah Umm al-Qur'a>n, 1999), 88.

${ }^{12}$ Ibid., 89.
} 
agama melampaui kerja demi kebendaan dan duniawi. Dengan mengutip firman Allah surah $\mathrm{A}<\mathrm{li}$ 'Imra $>\mathrm{n}$ ayat 110 mereka menjelaskan bahwa tujuan umat muslim dikeluarkan di tengah-tengah manusia adalah untuk berdakwah, mengajak orang ke jalan Allah seperti halnya para nabi. Dalam melaksanakan tugas berdakwah itu, umat Islam harus memiliki keberanian meninggalkan kehidupan dunianya sementara waktu, untuk memfokuskan diri mengajak orang mengamalkan ajaran Islam yang kafah. Karena bagaimana pun juga, manusia tidak boleh dibiarkan dalam kejahilan dan mesti didatangi ke tempat-tempat dimana mereka tinggal sambil dibujuk untuk bersedia mendalami Islam yang menyeluruh. $^{13}$

Pendekatan dakwah yang musti dilakukan menurut paradigma ini adalah mengajak masyarakat melalui nasehat-nasehat, dan membujuk mereka untuk berhijrah dari lingkungan yang melalaikan kepada lingkungan masjid. Mengembalikan mereka dari lembah kemaksiatan menuju ketaatan kepada Allah dan menjalani kehidupan mereka sehari-hari sesuai dengan syari'at Allah dan sunnah Rasul Nya, baik dalam menunaikan perkara-perkara fard $\}$, sunnah, hingga kebiasaan sehari-hari. Dalam peristilahan paradigma tablig, pendekatan dakwah yang berupa ajakan dan nasihat-nasihat tersebut dikenal dengan sebutan baya $>n$ (penjelasan). ${ }^{14}$

Dalam bingkai pemikiran tablig, para pelaku dakwah mesti mengenal pokokpokok dakwah yang enam ( $u s\} u>l$ al-da'wah al-sittah) yang disarikan dari enam karakter mulia sahabat. Para pendukung dakwah tablig meyakini, bahwa dengan mengingat dan merenungkan sifat enam tersebut dengan berusaha mempraktikkannya untuk diri sendiri dan mengajarinya kepada orang lain, merupakan jalan untuk membuka pintu agama dan menyebarkannya ke seluruh penjuru dunia. ${ }^{15}$ Enam pokok dakwah yang dimaksudkan secara berturut-turut; kembali kepada komitmen tauhid, shalat dengan khushu' dan khud\}u', ilmu beserta dzikir, memuliakan muslimin, meluruskan niat, yang paling penting adalah dakwah tabli>g khuru>j fi> sabi>lilla>h.

\footnotetext{
${ }^{13}$ Ibid.

${ }^{14}$ Ibid., 178.

${ }^{15}$ Ibid.
} 


\section{Paradigma Pengembangan Masyarakat}

Dalam Kamus Besar Bahasa Indonesia, pengembangan masyarakat dimaknai sebagai usaha untuk membangun masyarakat dari segenap aspeknya secara bertahap dan teratur menjurus ke arah atau tujuan yang dikehendaki. ${ }^{16}$ Jika pengertian ini dikaitkan dengan dakwah sebagai sosialisasi Islam, maka sekurangnya didapati hubungan mutualisme.

Pertama, dari segi tujuan, dakwah dan pengembangan masyarakat memiliki keterkaitan yang memperkuat satu sama lain. Dakwah dimaksudkan untuk mewujudkan kebaikan dan kemajuan hidup di dunia dan akhirat. Hal itu pula sesungguhnya yang ingin dicapai oleh seluruh usaha pengembangan masyarakat (community development). Jadi, kalu begitu dakwah itu sejatinya adalah jalan mengembangkan masyarakat. ${ }^{17}$

Kedua, dari segi metodologi pendekatan, dakwah dan pengembangan masyarakat memiliki hubungan yang saling melengkapi. Membangun masyarakat, tidak cukup hanya pada satu aspek, dengan melupakan aspek lainnya. Lebih dari itu, membangun masyarakat harus dilakukan secara komprehensif, baik fisik-materiil maupun moral-spiritual. Terkait dengan prespektif ini, dakwah wahana sosialisasi Islam berkepentingan untuk menjaga sisi moralitas dan spiritualitas masyarakat, di samping ikut mendorong aksi pembangunan masyarakat dari sisi material. Demikian itu, karena Islam sebagai tema sentral dakwah memahami manusia sebagai satu kesatuan yang utuh terdiri dari unsur material dan spiritual. Konsekuensi logis pendekatan ini menilai bahwa pembangunan masyarakat dari aspek materiil saja dengan melupakan aspek spiritualitas masyarakat sebagai usaha yang tidak komprehensif. ${ }^{18}$

Dakwah paradigma pengembangan masyarakat lebih mengutamakan aksi ketimbang wacana atau retorika (tablig). Karena itu, bentuk pemikiran dakwah ini

\footnotetext{
16 Tim Penyusun Kamus Besar Bahasa Indonesia, Kamus Besar Bahasa Indonesia (Jakarta: Departemen Pendidikan Nasional, 2008), 632.

${ }^{17}$ M. Quraish Shihab, Membumikan Al-Qur'an (Bandung: Mizan, 2006), 243.

${ }^{18}$ Bagi cendekiawan Nurkholis Madjid, kedudukan aspek spiritual yang didakwahkan agama ialah suatu yang amat fundamental. Disebut demikian, karena ia dapat memberikan kekuatan dan ketahanan suatu masyarakat. Ketuhanan yang Maha Esa adalah asas, yang di atasnya pengembangan masyarakat didirikan. Baca Nurkholis Madjid, Tradisi Islam Peran dan Fungsinya dalam Pembangunan di Indonesia (Jakarta: Paramadina, 2008), 172.
} 
tidak terkonsolidasi dalam sebuah mazhab formal tertentu yang sistematik dan dapat ditelaah sebagai rujukan. Namun demikian, sebagai bentuk gerakan dakwah, paradigma pengembangan masyarakat mengejawantah dalam lembagalembaga swadaya masyarakat muslim yang independen dari gerakan politik masif. Kegiatan dakwah paradigma pengembangan masyarakat biasanya beraksi dalam bidang-bidang sosial, ekonomi dan pendidikan seperti penyuluhanpenyuluhan, pengembangan ekonomi mikro dan menengah, pengembangan SDM dan pendidikan masyarakat madrasah atau pesantren. Gejala-gejala keagamaan yang terdapat dalam aksi-aksi tersebut sebagi bentuk sosialisasi Islam itulah yang mungkin ditelaah lebih jauh sebagai paradigma khusus dalam dakwah.

Dari segi metode dakwahnya, paradigma dakwah pengembangan masyarakat berusaha mewujudkan Islam dengan cara atau jalan menjadikan Islam sebagai pijakan pengembangan dan perubahan sosial yang bersifat transformatifemansipatoris. Demikian itu, karena menurut cara pandang dakwah pengembangan masyarakat, Islam adalah agama kemanusiaan dan profetik. Dikatakan demikian karena Islam dihadirkan demi kepentingan kelangsungan hidup manusia dan memberdayakan manusia dengan segenap potensinya sebagai wakil Allah di bumi. ${ }^{19}$ Dalam doktrin kitab suci, artikulasi ini dapat dipandang dengan ayat yang menyatakan bahwa tujuan diutusnya Nabi Muhammad tidak lain adalah sebagai rahmat bagi semesta alam, ${ }^{20}$ atau risalah Islam ini diwahyukan untuk mengangkat manusia dari kegelapan menuju cahaya. ${ }^{21}$ Kedua penegasan dari kitab suci itu menurut paradigma dakwah ini, harus terus-menerus menjadi basis kekuatan yang mampu memotivasi umatnya untuk melakukan transformasi masyarakat melalui pembangunan dan pengembangan konkret yang berorientasi pada masalah-masalah sosial, ekonomi serta penyadaran hak-hak politik masyarakat, dan bukannya pada masalah-masalah teologi atau politik ansich. Melalui paradigma ini, dakwah sejatinya dimasukkan sebagai bentuk perjuangan untuk mengembalikan semangat profetik Islam yang mewujudkan peranan para ilmuwan dalam proses perubahan masyarakat secara lebih mendasar, dengan

\footnotetext{
${ }^{19}$ Bagi cendekiawan Komaruddin Hidayat, agama itu dihadirkan untuk membantu mengembangkan seseorang dan masyarakat. Demikian itu, sebab agama pada watak dasarnya adalah kemanusiaan yang profetik. Dan karena itu, tidak seharusnya manusia yang berkorban demi institusi agama tertentu. Hidayat dalam pengantar Islam dan Hegemoni Sosial, Khaerani ed, Islam dan Hegemoni Sosial (Jakarta: Media Cita ,2002), xix.

${ }^{20}$ QS. 21:197

${ }^{21}$ QS. 2:257, 5:16, 14:5 dan 65:11.
} 
pendekatan historis, kultural dan struktural, berorentasi kerakyatan melalui pendekatan yang praktis. $^{22}$

Dalam konteks pemikiran Islam indonesia, paradigma pengembangan masyarakat ini dapat dinisbatkan kepada sejumlah pemikir seperti A. Mukti Ali, Dawam Raharjo, Adi Sasono dan Muslim Abdurrahman. Sebagai mantan menteri agama yang berbasis ilmu perbandingan agama, pemikiran Mukti Ali memiliki corak pengembangan masyarakat. Hal ini dapat dilihat dari ide dan gagasannya tentang agama sebagai landasan pembanguanan dan usulannya tentang modernisasi lembaga pendidikan pesantren, hingga gagasannya tentang badan zakat infak sedekah yang sekarang telah banyak berkembang. ${ }^{23}$ Adapun Dawam Raharjo adalah seorang penggiat LSM yang berlatar belakang pendidikan ekonomi. Pemikirannya yang bercorak pengembangan masyarakat melalui pesantren. ${ }^{24}$ Sementara itu, gagasan Islam transformatif yang terkait dengan sejumlah isu, seperti soal hubungan agama dan pembangunan nasional, pemberdayaan masyarakat, ekonomi kerakyatan, hingga emansipasi sosial, dimunculkan oleh tokoh-tokoh aktivis LSM seperti Adi Sasono dan Muslim Abdurrahman. Kedua tokoh islam ini, berlatar belakang pendidikan massingmasing tekno ekonomi dan sosiologi. ${ }^{25}$ Selain itu, organisasi-organisasi kemasyarakatan Islam independen (non politik) seperti Badan Kontak Majelis Taklim (BKMT) yang diprakarsai oleh $\mathrm{Hj}$. Tutty Alawiyah, atau gerakan Indonesia emas (ESQ) yang diprakarsai oleh Ari Ginanjar dan sejumlah lembaga serupa yang memiliki kontribusi besar dalam melakukan pemberdayaan masyarakat, dapat pula disebut sebagai representatif gerakan dakwah paradigma pengembangan masyarakat ini.

Sebagai suatu pemikiran dan gerakan, madzhab dakwah pengembangan masyarakat ini memiliki kekuatan dan keunggulan. Setidaknya, madzhab ini telah berperan dalam memperbaiki paham masyarakat bahwa dakwah, sejatinya tidak hanya pidato (tablig), tetapi transformasi sosial dan kultural menuju kualitas khairu ummah. Sasaran utama dakwah paradigma ini, seperti telah diutarakan,

\footnotetext{
${ }^{22}$ Syarifuddin Jurdi, Sosiologi Islam dan Masyarakat Modern (Jakarta: Prenada Media, 2010 ), 120.

${ }^{23}$ Lihat Aden Wijaya SZ, et al., Pemikiran dan Peradaban Islam (Yogyakarta: Safira Insania Press, 2007), 245.

${ }^{24}$ Ibid., 247.

${ }^{25}$ Ibid., 245.
} 
adalah perbaikan masyarakat dalam segala lini kehidupan, dengan memanfaatkan dan pengembangan potensi-potensi yang ada pada masyarakat itu sendiri. Sebagai gerakan sosial, gerakan dakwah paradigma ini, menjaga jarak dan memelihara independensinya dengan pemerintah dan semua kekuatan politik yang ada.

\section{Paradigma Harakah}

Dakwah harakah bermakna dakwah dengan atau melalui sistem pergerakan. Sesuai dengan namanya, aliran dakwah yang satu ini lebih menenkankan aspek tindakan (aksi) ketimbang wacana (teoretisasi). Menurut $\mathrm{H}\{$ asan al-Qat $\} \mathrm{t}\} \mathrm{a}>\mathrm{ni}>$, yang dimaksud dakwah harakah adalah dakwah yang berorientasi pada pengembangan masyarakat Islam, dengan melakukan reformasi total (is\}la>h\}) terhadap seluruh aspek kehidupan sosial, baik terkait dengan individu (is lla>h\} al-fard), keluarga (isfla>h\} al-usrah), masyarakat (isfla>h\} al-mujtama>'), hingga negara (is\}la>h\} al-dawlah). Dari definisi yang diutarakan oleh alQat\}t\}a>ni> ini kita dapat membedakan antara dakwah paradigma pengembangan masyarakat dan paradigma harakah. Keduanya memiliki kesamaan orientasi, pengembangan masyarakat, namun dari segi substansi dan cakupannya dakwah harakah mengklaim memiliki ruang gerak lebih komprehensif dibanding dakwah pengembangan masyarakat. Karena dakwah pengembangan masyarakat membatasi diri dari unsur politik, sedangkan paradigma harakah justru menilai politik sebagai salah satu bagian tak terpisahkan dari sistem Islam, sehingga dakwah tidak bisa dipisahkan dari politik. Dalam pandangan mereka, Islam disimbolkan dengan $3 \mathrm{D}$, di>n (agama), dawlah (negara) dan dunya $>$ (dunia). ${ }^{26}$

Adapun dari latar belakang, kemunculan dakwah harakah tidak hanya karena doktrin profetik Islam, seperti doktrin rahlmatan li al-' $a>l a m i>n$ atau $i k h r a>j$ min al-z\}uluma>t ila> al-nu>r saja. Tapi juga karena faktor historis, yaitu keterpurukan umat Islam pascakolonialisme di satu sisi dan kebangkitan Islam di

\footnotetext{
${ }^{26}$ Menurut Fath\}i Yakan, sebagai sistem hidup yang komprehensif, Islam tidak boleh dianggap hanya sistem keyakinan transendental, melainkan suatu sistem yang mengatur seluruh segi kehidupan dari sistem sosial, ekonomi hingga politik. Fath\}i Yakan, Kayfa Nad'u> ila $>$ al-Isla $>m$ (Beirut: Muassasah al-Risala>h, 1991), 89.
} 
sisi lain. $^{27}$ Menurut Ibrahim al-Ja'bari>, dakwah harakah sebagai sebuah paradigma memadukan dimensi pemikiran dan pergerakan mulai eksis bermunculan di negeri-negeri Islam sejak permulaan abad $20{ }^{28}$

Dari sudut pandang metode dakwah, pendekatan yang diterapkan dakwah harakah dalam beberapa hal memiliki kesamaan dengan paradigma pengembangan masyarakat. Misalnya, tentang sosialisasi tauhid sebagai asas pembangunan masyarakat, kebangkitan intelektual dan ekonomi atau kritik keduanya terhadap mazhab dakwah tablig. Akan tetapi, mazhab harakah berangkat lebih jauh ketika mengusulkan dakwah juga harus mencakup perbaikan negara atau pemerintahan. Untuk mewujudkan hal ini mereka melakukan pendekatan dakwah massif. Contoh dakwah paradigma harakah adalah al-Ikhwan al-Muslimun.

\section{Paradigma Kultural}

Dakwah paradigma kultural merupakan turunan dari penafsiran Islam yang bercorak kultural dan dinamis-dialogis. Menurut paradigma Islam kultural, Islam sebagai agama universal, terbuka untuk ditafsirkan sesuai dengan konteks budaya lokal tanpa takut kehilangan orisinalitasnya. Alur pemikiran ini menegaskan bahwa Islam pada dasarnya natural, selaras dengan kecendrungan alamiah manusia di manapun berada. Islam mampu mengakomodasi setiap budaya dan turut memberi warna kepada setiap budaya yang disinggahinya. ${ }^{29}$ Pandangan ini membedakan antara Islam dan budaya, termasuk budaya yang lahir pertama kali ketika persentuhan Islam dengan masyarakat Arab. Mereka menganggap pensakralan budaya Islam awal sama saja mencederai karakteristik universalisme Islam. Ketika pensakralan itu dilanjutkan sebagai sebuah idealisme dakwah, maka yang terjadi adalah normativitas dan formalitas beragama. Menurut paradigma kultural, inilah kesalahan yang terjadi pada mazhab dakwah harakah. Menurut paradigma kultural, kesalahan ini menjadikan paradigma dakwah harakah tampak kaku dan tidak peka terhadap unsur-unsur kebijaksanaan lokal dan kontekstual.

\footnotetext{
${ }^{27} \mathrm{Yu}>\mathrm{suf}$ al-Qard $\} \mathrm{a}>\mathrm{wi}>$, S\{ahwah al-Isla>miyah wa Humu>m al-Wat $\} a>n$ al-'Arabi $>$ wa al-Isla $>m i>$ (Kairo: Maktabah Wahbah, 1997), 29.

${ }^{28}$ Ibrahim Muhammad al-Ja'bari, Gerakan Kebangkitan Islam, terj. Abu Ayyub (Solo: Duta Rahman, 1996), 67-70.

${ }^{29}$ Abu Yasid, Islam Akomodatif: Rekonstruksi Pemahaman Islam sebagai Agama Universal (Yogyakarta: LKIS, 2004), 34.
} 
Untuk menghindari kesalahan yang sama, mazhab kultural menempuh jalur yang lebih lunak dan substansif dalam berdakwah. Mereka membedakan Islam dari dua sisi, normatif dan esoteris. Untuk menyosialisasikan Islam, dakwah kultural cenderung menekankan sisi substansif-esoteris sebagai pendekatan dakwah.

Paradigma kultural berpendapat sejarah Islam dari pertama kelahirannya hingga saat ini selalu diwarnai dengan proses akulturasi timbal balik. ${ }^{30}$ Pada saat Islam hadir dalam suatu pola budaya tertentu, terkadang ia memberikan corak dominan dalam budaya tersebut, pada saat yang lain Islam hanya memberi sentuhan warna saja. Pendukung dakwah ini berpendapat bahwa dakwah semua rasul tidak pernah lepas dari proses dialog dengan kultur setempat dimana mereka diutus. $^{31}$

Dakwah paradigma ini memiliki beberapa keuntungan dibanding dakwah harakah. Pertama, kehadiran dakwah Islam tidak dianggap sebagai ancaman bagi eksistensi budaya lokal. Kedua, dengan menerima dakwah Islam tidak berarti suatu kaum terputus dari masa lampaunya. Ketiga, universalisme Islam tidak hanya dianggap sebagai wacana, karena kehadiran Islam tidak dirasakan sebagai sesuatu yang asing, namun bagian yang integral dari budaya lokal. Keunggulan lain dakwah kultural, yakni penegasan watak universalisme Islam melalui kehadirannya yang indigenous di tengah budaya baru. Berbeda dengan mereka yang memandang universalisme Islam sebagai sistem hidup menyangkut seluruh aspek kehidupan manusia, mazhab kultural lebih memandang universalisme Islam sebagai kemampuan mengakomodasi pluralitas budaya manusia. Berangkat dari pandangan humanismenya, dakwah Islam masuk ke dalam pola budaya yang bermacam-macam tanpa membawa kesan asing. Ini semua karena dakwah dilakukan dengan pendekatan kemanusiaan. Suatu pendekatan dakwah yang menekankan natur (karakter alamiah) manusia sebagai suatu yang konstan, tidak terpengaruh oleh tepat dan zaman, asal-usul ras maupun bahasa.

\footnotetext{
${ }^{30}$ Nurkholis Madjid, Islam Doktrin dan Peradaban (Jakarta: Paramadina, 2008), 537.

${ }^{31}$ Abdul Munir Mulkhan mengutip ayat 4 surah Ibrahim yang menjelaskan bahwa seorang rasul tidak diutus kecuali dengan lisan kaumnya. Menurutnya pemahaman lisan disini bukan sekedar bahasa, tetapi budaya lokal termasuk adat istiadat. Abdul Munir Mulkhan, Kesalehan Multikultural: Berislam secara Autentik-Kontekstual di Arus Peradaban Global (Jakarta: PSAP Muhammadiyah, 2005), 223.
} 
Dengan pendekatan budaya lokal ini, dakwah Islam tidak canggung mengadopsi aneka ragam bentuk budaya dengan mengisinya muatan bernilai Islam. Paradigma kultural menghendaki dakwah ditampilkan secara inklusif bukan eksklusif. Dalam konteks keindonesiaan klasik, praktek dakwah wali songo merupakan representasi dakwah kultural. Memasuki era kontemporer, mereka yang masuk dalam jajaran mazhab kultural adalah Abdurrahman Wahid, Nurkholis Madjid, Amin Abdullah dan Abdul Munir Mulkhan.

\section{ELABORASI KONSEP DAKWAH YANG DIMILIKI PAKAR DAKWAH}

Sebagai salah satu bagian dari keilmuwan Islam, konsep dakwah yang dikemukakan para ahli tidak lepas dari pengertian dakwah secara bahasa yang berarti memanggil, mengundang, meminta, memohon, menamakan, mendorong, menyebabkan, mendatangkan, mendoakan, menangisi dan meratapi. ${ }^{32}$ Berikut adalah konsep dakwah yang dikemukakan para ahli. ${ }^{33}$

Imam Sayuti Farid menyatakan dakwah adalah proses penyampaian ajaran Islam kepada umat manusia dengan asas, cara serta tujuan yang dapat dibenarkan oleh ajaran Islam itu sendiri. Hafi Anshori menyebutkan dakwah merupakan proses penyelenggaraan suatu usaha untuk mengajak orang beriman dan menaati Allah, amar ma'ruf, perbaikan dan pembangunan masyarakat, dan nahi munkar yang dilakukan dengan sengaja dan sadar untuk mencapai tujuan tertentu, yaitu kebahagiaan dan kesejahteraan hidup yang diridhai Allah. Sementara Jamaluddin Kafie memberikan konsep bahwa dakwah merupakan suatu sistem kegiatan dari seseorang, kelompok, atau segolongan umat Islam sebagai aktualisasi imaniyah yang dimanifestasikan dalam bentuk seruan, ajakan, panggilan, undangan, dan doa. Semua itu disampaikan dengan ikhlas menggunakan metode, sistem, dan bentuk tertentu, agar mampu menyentuh kalbu dan fitrah seseorang, sekeluarga, sekelompok, dan masyarakat supaya dapat mempengaruhi tingkah laku untuk mencapai tujuan tertentu.

\footnotetext{
${ }^{32}$ Lihat Ahmad Warson Munawwir, al-Munawwir Kamus Arab-Indonesia (Surabaya: Pustaka Progresif, 1997), 406.

${ }^{33}$ Dikutip dari buku Ilmu Dakwah karya Mohammad Ali Aziz. Lebih lanjut lihat Mohammad Ali Aziz, Ilmu Dakwah (Jakarta: Kencana, 2004), 11-17.
} 
M. Arifin memberikan pengertian dakwah sebagai kegiatan ajakan dalam bentuk lisan, tulisan, tingkah laku dan sebagainya yang dilakukan secara sadar dan terencana dalam usaha mempengaruhi orang lain secara individu maupun kelompok. Hal ini supaya timbul dalam dirinya suatu pengertian, kesadaran, sikap, penghayatan, serta pengamalan terhadap ajaran agama, tanpa ada unsur paksaan. ${ }^{34}$

Sementara dari pakar Timur Tengah, 'Ali $>\mathrm{Mah}\} \mathrm{fu}>\mathrm{dh}$ memberikan definisi dakwah sebagai usaha memotivasi manusia untuk berbuat kebaikan, mengikuti petunjuk, memerintahkan kebaikan dan mencegah kemungkaran agar manusia memperoleh kebahagiaan di dunia dan akhirat. ${ }^{35} \mathrm{Abu}>$ Bakar Zakariya memberikan pengertian, dakwah adalah usaha para ulama dan orang-orang yang memiliki pengetahuan agama Islam untuk memberikan pengajaran kepada khalayak umum sesuai dengan kemampuan yang dimiliki tentang hal-hal yang mereka butuhkan dalam urusan dunia dan keagamaan. Muhammad al-Gazali> menyebutkan dakwah sebagai program sempurna yang menghimpun semua pengetahuan yang dibutuhkan manusia di semua bidang, agar ia dapat memahami tujuan hidupnya serta menyelidiki petunjuk jalan yang mengarahkannya menjadi orang-orang yang mendapat petunjuk.

Terlihat dari beberapa konsep tersebut, para ahli setuju bahwa dakwah adalah informatif-persuasif, bukan termasuk dakwah jika ada unsur pemaksaan dalam prosesnya. Dalam hal ini M. Arifin secara spesifik menyebutkannya, menurut penulis ini bisa dilacak dari basic keilmuwan Arifin yang notabene adalah psikolog, dalam dunia psikologi tidak ada seruan yang memaksakan. Dakwah juga tidak manipulatif, sehingga bukan dakwah jika yang terjadi adalah pemutar balikkan fakta tentang Islam sehingga orang tertarik masuk Islam, juga pemutar balikkan fakta yang lainnya. Terlihat dalam merumuskan tujuan dakwah, para ahli sangat intens menyinggungnya, walaupun ada yang menyebutkan tujuannya untuk kepentingan dunia akhirat, seperti 'Ali> Mah $\} \mathrm{fu}>\mathrm{dh}$, serta ada pula yang hanya untuk tujuan dunia, seperti Hafi Anshori, dan ada yang tidak menyebutkan secara eksplisit. Dalam perspektif ilmiah, kita dapat menggambarkan dan mengukur tujuan dunia, tetapi tidak dapat mengukur tujuan akhirat. Karena tujuan akhirat tidak dapat diukur dengan diuji secara empiris ilmiah.

\footnotetext{
${ }^{34}$ M. Arifin, Psikologi Dakwah suatu Pengantar Studi, cet. kelima (Jakarta: Bumi Aksara, 2000), 6.

35 'Ali> Mah\}fu>dh, Hida $>$ yat al-Murshidi $>n$ (Kairo: Da>r al-Kutub al-'Arabiyyah, 1952), 1.
} 
Menurut Ali Aziz, para pakar dakwah Indonesia sering menonjolkan aspek metode dakwah. Berbeda dengan penulis Timur Tengah yang umumnya menekankan aspek pesan dakwah. ${ }^{36}$ Menurut penulis hal ini karena kondisi Indonesia yang lebih menekankan pada aspek metode dakwah, karena di Indonesia menghadapi berbagai macam etnik dan budaya. Walaupun mayoritas masyarakat Indonesia bergama Islam, namun kebanyakan masih belum memahami Islam, bahkan ajaran Islam yang mereka amalkan masih bercampur baur dengan klenik. Menghadapi orang-orang seperti inilah diperlukan beragam metode yang seusai. Dibandingkan dengan Timur Tengah yang lebih homogen masyarakatnya, dan kebanyakan mereka pun sudah memeluk Islam, jadi fokus nya adalah pada pesan dakwahnya, bukan pada metodenya.

Secara umum konsep dakwah yang dikemukakan para ahli menunjuk pada kegiatan yang bertujuan membuat perubahan positif dalam diri manusia. Perubahan positif ini diwujudkan dengan peningkatan iman, karena sasaran dakwah adalah iman. Karena tujuannya baik, maka kegiatannya juga harus baik. Walaupun terdapat beberapa perbedaan redaksi dalam konsep yang ditawarkan para ahli tersebut, konsep itu menyempit pada rumus sebagai berikut :

a. Dakwah merupakan suatu aktifitas atau usaha yang dilakukan dengan sengaja atau sadar.

b. Usaha tersebut berupa ajakan ke jalan Allah dengan amar ma'ruf nahi munkar.

c. Usaha tersebut dimaksudkan untuk mencapai cita-cita dari dakwah, yaitu menuju kebahagiaan manusia di dunia maupun akhirat.

Persoalannya adalah, dalam konsep-konsep tersebut sangat memposisikan pelaku dakwah yaitu da'i sebagai penyampai pesan agama, sebagai seorang yang superior. Dengan segala usaha mereka membuat "garapannya" terpengaruh dan mau mengikuti apa yang mereka inginkan. Dalam hal ini menganggap apa yang dibawa oleh da'i adalah sebuah kebenaran dan mad'u harus mengikutinya. Konsep seperti ini sangat ekslusif, bahkan tidak ada indikasi kerjasama atau kebersamaan atau proses timbal balik antara da'i dan mad'u yang berlangsung secara dialogis.

${ }^{36}$ Ali Aziz, Ilmu Dakwah, 18. 


\section{TANTANGAN DAKWAH DI TENGAH KOMPLEKSITAS MASYARAKAT}

Dalam era sekarang ini, peranan dakwah akan lebih meningkat dan penting karena tantangan-tantangan yang dihadapi di masa mendatang lebih kompleks dan masyarakat menuntut layanan agama yang dapat memberi motivasi dan bekal untuk memecahkan masalah duniawi yang semakin kompleks. Secara umum ada tiga tantangan yang dihadapi masyarakat. Pertama masyarakat telah berubah dari agraris menjadi masyarakat industri. Dalam hal ini masyarakat industri memiliki pola hidup mewah dan hedonistik, cenderung lebih rasional dan lebih otonom dalam perencanaan, produksi, pemasaran dan promosi industri. Situasi demikaian secara kejiwaan membawa mereka cenderung kurang merasa perlu terhadap agama dan karenanya akan menjadi jauh dari ajaran moral agama.

Kedua, globalisasi informasi. Pada masa ini kita dibanjiri oleh budaya, pola hidup dan tata nilai global yang tidak selalu menunjang usaha pemupukan budi pekerti luhur. Ketiga, makin tingginya tingkat intelektualitas, terutama di kalangan muda. Mereka tentunya memiliki daya kritis yang semakin kuat dan tidak mau begitu saja menerima kata serta pendapat orang lain. Mereka akan minta penjelasan yang rasional dan dapat diterima akal mereka. ${ }^{37}$

Melihat kondisi seperti ini diperlukan adanya dakwah multi dialog, integratif dan fungsional. Dakwah dalam hal ini dapat diformulasikan sebagai proses interaksi umat Islam dengan umat manusia secara keseluruhan, yang bertujuan untuk mengenalkan nilai-nilai Islam dan konsep Islam yang operasional dan mengupayakan realisasinya dalam kehidupan umat manusia. Untuk itu, maka pesan dakwah harus mencakup seluruh aspek kehidupan umat manusia, baik pada tataran individu maupun komunitas. Dalam keadaan seperti ini, maka dakwah perlu dilakukan dalam bentuk dialog kehidupan manusia dalam berbagai aspeknya.

Pada tingkat individu, dakwah dapat berupa dialog informasi, dialog nilai, ide, budaya, karya, spiritual, sosial, politik, ekonomi dan berbagai aspek lainnya. Dengan dialog, segala masalah dapat ditelusuri dan semua pihak dapat ikut aktif dalam proses tersebut. dalam hal ini antara da'i dan mad'u tidak terdapat jurang kesenjangan yang dalam, tidak ada kesan da'i powefull dan mad'u pihak yang pasif. Dalam dialog, tidak

\footnotetext{
${ }^{37}$ Abdul Basit, Wacana Dakwah Kontemporer (Yogyakarta: Pustaka Pelajar, 2006), 151-152.
} 
ada yang merasa paling berjasa dan tidak ada yang merasa diberi jasa. Dialog tidak membedakan struktur dan kedudukan dalam komunitas sosial, semua peserta ikut ambil bagian.

Dakwah integratif dan fungsional. Dakwah masa depan adalah membangun dan mengembangkan masyarakat. Maka dakwah harus integratif, menyatu dengan kehidupan masyarakat dan membangun kesadaran tunggal akan makna dan misi pembangunan dan perubahan. Dalam situasi masa depan, dakwah harus dapat membaca peluang, celah mana yang dapat dimasuki untuk menyatukan visi dan misi. Dakwah dijabarkan melalui kegiatan sosial yang aktual dan berpijak dari dasar persoalan dan kebutuhan masyarakat yang sedang dirasakan.

Sifat integratif dakwah menuntut dakwah dipersiapkan dan berangkat dari dalam situasi dan kondisi masyarakat. Interaksi antara da'i dan masyarakat lebih intens dan sejajar, sehingga memahami dan merasakan apa yang dirasakan masyarakat.

Dakwah fungsional adalah yang secara nyata mampu menjawab persoalanpersoalan riil yang muncul dalam masyarakat. Dakwah fungsional berarti upaya menumbuhkan kesadaran umat dan membuktikan kepada umat bahwa apabila ajaran Islam dipahami secara benar dan dilaksanakan serta diimplementasikan dalam kehidupan, maka ia akan bisa mengatasi dan mencari alternatif jalan keluar.

Secara esensial, dakwah berkaitan dengan bagaimana membangun dan membentuk masyarakat yang baik, berpijak pada nilai-nilai kebenaran dan hak asasi manusia. Dalam pengertian non-konvensional inilah, dakwah dapat berhubungan secara kultural-fungsional dengan penyelesaian problem kemanusiaan, termasuk problem sosial. Beberapa strategi untuk pengembangan dakwah agar dapat menyelesaikan problem yang ada :

Dakwah harus dimulai dengan mencari kebutuhan masyarakat. Kebutuhan ini bukan hanya kebutuhan obyektif yang perlu dipenuhi, tapi kebutuhan yang perlu mendapat perhatian. Dakwah dilakukan secara terpadu, dalam artian bahwa berbagai aspek kebutuhan masyarakat dapat dijangkau program dakwah, dapat melibatkan berbagai unsur yang ada dalam masyarakat. Penyelenggaraan program dakwah itu merupakan rangkaian yang tidak terpisah. 
Dakwah dilakukan dengan pendekatan partisipasi dari bawah. Ide yang ditawarkan mendapat kesepakatan masyarakat, atau merupakan ide masyarakat itu sendiri. Hal ini memberi peluang keikutsertaan masyarakat dalam perencanaan dan keterlibatan mereka dalam program dakwah. Dakwah dilaksanakan melalui proses sistematika pemecahan masalah. Dengan demikian masyarakat terbiasa bekerja terencana, efisien, dan mempunyai tujuan jelas.

\section{PENUTUP}

Konsep pemikiran dakwah yang ada selama ini lebih mengarah pada pola positivistik yang kaku, meniadakan dialog serta memposisikan da'i sebagai manusia super di atas kepasifan mad'u. Sementara perkembangan jaman yang semakin canggih membuat agama semakin terprivatisasi, menjadikan masyarakat semakin aktif, kritis dan dinamis. Hal ini meniscayakan sebuah konsep dakwah yang humanis, dialogis, mengusung kesetaraan peran antara da'i dan mad'u serta tidak memposisikan mad'u sebagai pihak yang pasif, hanya menerima apa yang disampaikan da'i.

Sebagai agama dakwah yang menjadi rahmat untuk seluruh alam, dakwah harus segera berbenah diri. Fenomena maraknya manusia yang semakin menjauh dari ajaran agama saat ini tidak bisa hanya menyalahkan kemajuan teknologi dan melemahnya iman masyarakat, tapi juga harus dipertimbangkan kurang relevannya konsep dakwah yang akhirnya dipraktekkan dalam aktifitas dakwah di masyarakat.

Dakwah yang efektif adalah dakwah yang dapat memberikan tidak hanya sebatas keinginan masyarakat, akan tetapi lebih dari itu adalah apa yang menjadi kebutuhan mereka. Untuk itu, khazanah obyektifitas terhadap keadaan masyarakat mutlak diperlukan. Pada kegiatan berikutnya akan diwujudkan dalam bentuk kepercayaan dakwah dalam matriks dakwah yang masing-masing mempunyai titik konsentrasi sendiri-sendiri. Sehingga pada nantinya, dalam tahapan pergerakan dakwah, konsep itu dapat diaktualisasikan sebagaimana kondisi obyektif yang ada di masyarakat. 


\section{BIBLIOGRAFI}

'Abd al-Majid, Muh \}ammad Junayd. Jama>'at al-Tabli>g fi> al-Hind Dira>sah wa alTaqwi>m. Makkah: Mat\}ba'ah al-Jama>'ah Umm al-Qur'a>n, 1999.

Achmad, Amrullah. Dakwah Islam dan Perubahan Sosial. Yogyakarta: PLP2M, 1983.

Ahmed, Akbar S. Posmodernisme: Bahaya dan Harapan bagi Islam, terj. M. Sirozi. Bandung: Mizan, 1993.

Anwar, Muhammad Syafi'i. Pemikiran dan Aksi Islam Indonesia: Sebuah Kajian Politik tentang Cendekiawan Muslim Orde Baru. Jakarta: Paramadina, 1995.

Arnold, Thomas W. Sejarah Dakwah Islam, terj. Abdullah. Jakarta: Widjaya, 1981.

Aziz, Mohammad Ali. Ilmu Dakwah. Jakarta: Kencana, 2004.

Basit, Abdul. Wacana Dakwah Kontemporer. Yogyakarta: Pustaka Pelajar, 2006.

Baya>nu>ni> (al), Muh\}ammad Abu> al-Fath\}. al-Madkhal ila> 'Ilm al-Da'wah. Beirut: Muassasat al-Risa>lah, 1993.

Cooper, John et. al., Pemikiran Islam dari Sayyid Ahmad Khan hingga Nasr Hamid Abu Zayd (Jakarta: Erlangga, 2000).

Daftary, Farhad ed,. Tradisi-Tradisi Intelektual Islam, terj. Fuad Jabali dan Udjang Tholib (Jakarta: Erlangga, 2001), 29-34.

$\mathrm{H}\{\mathrm{ima}>\mathrm{yah}, \mathrm{Mah}\} \mathrm{mu}>\mathrm{d}$ 'Ali>. Sabi $>l$ al-Rashi>d fi> al-Da'wah wa al-Irsha>d. Kairo: Da>r al-Ma’a>rif, 1993.

Hakim, Abdul. "Epistemologi Positivistik dalam Kajian Historis dan Metodologis", Ilmu Ushuluddin, vol. 5. Januari-Juni, 2006.

Hawton, Hector. Filsafat yang Menghibur: Penjelajahan Memasuki Ide-Ide Besar, terj. Supriyantono Abdullah. Yogyakarta: Ikon Teralitera, 2003.

Hodgson, Marshall G. S. The Venture of Islam: Iman dan Sejarah dalam Peradaban Dunia, buku kedua, terj. Mulyadhi Kartanegara. Jakarta: Paramadina, 2002.

Hourani, Albert. Pemikiran Liberal di Dunia Arab, terj. Suparno, et.al. Bandung: Mizan, 2004.

Ilaihi, Wahyu dan Harjani Hefni Polah. Pengantar Sejarah Dakwah. Jakarta: Kencana Prenada, 2012.

Ismail, Ilyas dan Prio Hotman. Filsafat Dakwah; Rekayasa Membangun Peradaban Islam. Jakarta: Kencana: 2011.

Ja'bari (al), Ibrahim Muhammad. Gerakan Kebangkitan Islam, terj. Abu Ayyub. Solo: Duta Rahman, 1996.

Jurdi, Syarifuddin. Sosiologi Islam dan Masyarakat Modern. Jakarta: Prenada Media, 2010.

Kennedy, Hugh. The Prophet and the Age of the Caliphates. London: Logman, 1991.

Khaerani ed, Islam dan Hegemoni Sosial. Jakarta: Media Cita ,2002.

Kurzman, Charles. Wacana Islam Liberal: Pemikiran Islam Kontemporer tentang Isu-Isu Global, terj. Bahrul Ulum et.al. Jakarta: Paramadina, 2001.

Lapidus, Ira M. Sejarah Sosial Umat Islam, bag.1 dan 2, terj. Ghufron A. Mas'adi. Jakarta: Raja Grafindo Persada, 2000.

M. Arifin, Psikologi Dakwah suatu Pengantar Studi, cet. kelima. Jakarta: Bumi Aksara, 2000.

Madjid, Nurkholis. Islam Doktrin dan Peradaban. Jakarta: Paramadina, 2008.

--------, Tradisi Islam Peran dan Fungsinya dalam Pembangunan di Indonesia. Jakarta: Paramadina, 2008.

Mah\}fu>dh, 'Ali>. Hida >yat al-Murshidi>n. Kairo: Da>r al-Kutub al-'Arabiyyah, 1952.

Muhadjir, Noeng. Filsafat Ilmu: Positivisme dan Postmodernisme. Yogyakarta: Rake Sarasin, 2001. 
Mulkhan, Abdul Munir. Kesalehan Multikultural: Berislam secara Autentik-Kontekstual di Arus Peradaban Global. Jakarta: PSAP Muhammadiyah, 2005.

Munawwir, Ahmad Warson. al-Munawwir Kamus Arab-Indonesia. Surabaya: Pustaka Progresif, 1997.

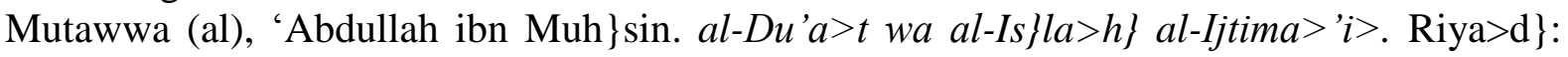
$\mathrm{Da}>\mathrm{r}$ al-H $\{\mathrm{ad}\} \mathrm{a}>\mathrm{rah}, 2009$.

Nasr, Seyyed Hossein. Islam Religion History and Civilization. New York: Harper San Fransisco, 2003.

Qard $\} a>w i>(a l), Y u>$ suf. S\{ahwah al-Isla $>$ miyah wa Humu>m al-Wat $\} a>n$ al-'Arabi> wa al-Isla>mi $>$ Kairo: Maktabah Wahbah, 1997.

Sardar, Ziauddin. Tantangan Dunia Islam Abad 21: Menjangkau Informasi. Bandung: Mizan, 1985.

Shihab, M. Quraish. Membumikan Al-Qur'an. Bandung: Mizan, 2006.

Siba'i (al), Mustafa Husni. Khazanah Peradaban Islam, terj. Abdullah. Bandung: Pustaka Setia, 2002.

Sulthon, Muhammad. Desain Ilmu Dakwah: Kajian Ontologis, Epistemologis dan Aksiologis. Yogyakarta: Pustaka Pelajar, 2003.

$\mathrm{T}\{\mathrm{a}>$ wir (al), H \{asan Mas'u $>\mathrm{d}$ al-Da'wah ila $>$ Alla $>h$ Ta'a $>l a>$ 'ala $>D\{a u$ 'i al-Kita $>b$ wa al-Sunnah. Beirut: Dar al-Qutaybah, 1992.

Tim Penyusun, Kamus Besar Bahasa Indonesia. Jakarta: Departemen Pendidikan Nasional, 2008.

Titus, Harold H. et.al., Persoalan-Persoalan Filsafat, terj. M. Rasjidi. Jakarta: Bulan Bintang, 1984.

Wijaya, Aden SZ, et al. Pemikiran dan Peradaban Islam. Yogyakarta: Safira Insania Press, 2007.

Yakan, Fath\}i. Kayfa Nad'u> ila> al-Isla>m. Beirut: Muassasah al-Risala>h, 1991.

Yasid, Abu. Islam Akomodatif: Rekonstruksi Pemahaman Islam sebagai Agama Universal. Yogyakarta: LKIS, 2004. 